Dr IGOR Đ. VUKADINOVIĆ, istraživač-saradnik

Balkanološki institut SANU

Beograd, Republika Srbija

UDK 316.7(497.1:496.5)"1967/1971"(093.2)

vukadinovicigor3@gmail.com

originalan naučni rad / original scientific paper

primljeno / received: 18. 12. 2020.

prihvaćeno / accepted: 19. 5. 2021.

https://doi.org/10.29362/ist20veka.2021.2.vuk.375-396

\title{
KULTURNO I EKONOMSKO POVEZIVANJE ALBANIJE I KOSOVA I METOHIJE 1967-1971.
}

APSTRAKT: Promene u položaju autonomnih pokrajina u Srbiji krajem šezdesetih godina 20. veka odrazile su se na odnose Kosova i Metohije sa Albanijom. Državni sekretarijat za inostrane poslove i Savezno izvršno veće počeli su 1967. godine da ohrabruju kulturno i ekonomsko povezivanje Kosova $i$ Metohije sa Albanijom, objašnjavajući to strategijom za normalizaciju odnosa između Jugoslavije i Albanije. Nakon skupova u Prištini i Tirani i međusobnih poseta prosvetnih delegacija, dogovoreno je da se udžbenici iz Albanije koriste u školskom sistemu Kosova i Metohije, a kosovska preduzeća su svoju proizvodnju preusmerila na albansko tržište. Profesori Univerziteta u Tirani angažovani su u nastavi na prištinskim fakultetima. Izveštaji albanskih predavača iz Prištine omogućili su partijskom vrhu Albanije širok spektar informacija o situaciji u Jugoslaviji. Rad se primarno zasniva na neobjavljenoj arhivskoj građi Centralnog državnog arhiva Albanije u Tirani, uz korišćenje dokumenata iz srpskih arhiva kao i objavljenih istorijskih izvora i literature.

KLJUČNE REČI: Albanija, Kosovo i Metohija, Jugoslavija, kultura, ekonomija, Univerzitet u Prištini, Univerzitet u Tirani

\section{Uvod}

Albanski funkcioneri u Pokrajinskom komitetu Saveza komunista Srbije za Kosovo i Metohiju iskoristili su promene izazvane Brionskim plenumom 1966. godine za pokretanje kampanje sa ciljem povećanja kosovskometohijske autonomije i jačanja položaja Albanaca u Jugoslaviji. ${ }^{1} \mathrm{U}$ tome su imali podršku

\footnotetext{
${ }^{1} \mathrm{O}$ političkoj situaciji u Srbiji i međunacionalnim odnosima na Kosovu i Metohiji posle Brionskog plenuma videti: Arhiv Jugoslavije (AJ), fond 507, Centralni komitet Saveza komunista Jugoslavije (CK SKJ), II-28, Četvrti plenum CK SKJ, kutija 2, Stenografske beleške sa Četvrte sednice CK SKJ, održane 1. jula 1966. na Brionima, 69-70; AJ, fond 837, Kabinet Predsednika Republike (KPR), II-2/316, Prijem delegacije Kosova i Metohije 23. februar 1967, Zabeleška o prijemu 4-19. marta 1967; Arhiv Srbije (AS), Đ-2, CK SKS, k. 22, Ocene deformacija u SUP-u
} 
najmoćnijih političkih figura u zemlji - Josipa Broza, Edvarda Kardelja i Vladimira Bakarića. Oslabljeni vrh Saveza komunista Srbije je na Šestoj sednici Centralnog komiteta Saveza komunista Srbije 14. i 15. septembra 1966. bespogovorno prihvatio tezu albanskih rukovodilaca da su Albanci bili u ,neravnopravnom položaju“ $i$ da su trpeli represiju od strane jugoslovenske UDBE, te da je neophodna promena državne politike prema Kosovu i Metohiji. ${ }^{2}$ Pored predloga za smanjivanje republičkih ovlašćenja $u$ pokrajinama, na partijskim sastancima su isticani i zahtevi da se Albancima iz Jugoslavije omoguće specijalne veze sa Narodnom Republikom Albanijom. ${ }^{3}$

Savezni sekretarijat za inostrane poslove (SSIP) doneo je 1966. godine u spoljnopolitičkim smernicama preporuku da se Jugoslavija ne osvrće na napade iz Albanije i da se prema ovoj zemlji ophodi prijateljski, kako bi postepeno došlo do normalizacije bilateralnih odnosa, koji su od 1948. godine bili obeleženi neprijateljstvom i nepoverenjem. ${ }^{4}$ Sekretar za inostrane poslove Marko Nikezić je u ekspozeu u Saveznoj skupštini krajem januara 1967. istakao da je jugoslovenska vlada spremna na poboljšanje odnosa sa Albanijom i saradnju sa ovom zemljom oko praktičnih pitanja u obostranom interesu. ${ }^{5} \mathrm{U}$ smernicama SSIP-a od 14. februara 1967. Autonomnoj pokrajini Kosovu i Metohiji namenjena je posebna uloga u otopljavanju odnosa sa Albanijom. Preporučena je kupovina literature iz Albanije za potrebe albanske manjine u Jugoslaviji, razmena publikacija, materijala i stručnjaka, kao i zajednički angažman Kosova i Metohije i Albanije na standardizaciji albanskog jezika. ${ }^{6}$

i DB-u, njihovi uzroci, idejni koreni i posledice i predlog mera za njihovo razrešavanje; Rajko Vidačić, O korenima separatizma i terorizma na Kosovu (Beograd: Službeni glasnik, 2000), 148-149; Miomir Gatalović, Burna vremena: Kosovo i Metohija u državnoj politici Jugoslavije 1966-1969 (Beograd: Institut za savremenu istoriju, 2018), 25-43, 354-355; Kosta Nikolić i Srđan Cvetković, Srbi i Albanci na Kosovu i Metohiji u 20. veku (1912-1990) (Beograd: Institut za savremenu istoriju, 2014), 290-292.

${ }^{2}$ U zaključcima sa sednice navedeno je da su delovi Službe državne bezbednosti činili „diskriminacije i nasilja naročito prema albanskoj narodnosti, što predstavlja drastičan vid šovinističke prakse“. Videti: Šesta sednica CK Srbije. Aktivnosti Saveza komunista Srbije posle Četvrte sednice SK Jugoslavije (Beograd: Sedma sila, 1966), 323; Vojin Lukić, Sećanja i saznanja. Aleksandar Ranković i Brionski plenum (Titograd: N. Jovović, 1989), 181; Dobrica Ćosić, Lična istorija jednog doba. Vreme iskušenja 1951-1968 (Beograd: Službeni glasnik, 2009), 253-255; M. Gatalović, Burna vremena, 51-54.

${ }^{3}$ AJ, 507, CK SKJ, XXIIIA-K. 3/1, Stenografske beleške sa sednica Komisije za međunacionalne i međurepubličke odnose 21. septembra 1967, str. 49. Kolj Široka je za loše odnose Jugoslavije i Albanije optužio velikosrpske elemente u Upravi državne bezbednosti. Videti: Šesta sednica CK Srbije. Aktivnosti Saveza komunista Srbije posle Četvrte sednice SK Jugoslavije, 58-60.

${ }^{4}$ Diplomatski arhiv Ministarstva spoljnih poslova Republike Srbije (DA MSP), Politička arhiva (PA), Albanija, 1967, fascikla (f.) 1, dosije (d.) 2, Informacija o stanju odnosa između SFR Jugoslavije i NR Albanije, 14. 2. 1967.

${ }^{5}$ DA MSP, PA, Albanija, 1967, f. 1, d. 2, Dokumentacija u vezi sa stanjem odnosa između SFR Jugoslavije i NR Albanije tokom 1965. i 1966. godine, Zvanične jugoslovenske izjave o Albaniji, 7.

${ }^{6}$ DA MSP, PA, Albanija, 1967, f. 1, d. 2, Informacija o stanju odnosa između SFR Jugoslavije i NR Albanije, 14. 2. 1967. 
Savezno izvršno veće (SIV) je 8. marta 1967. odlučilo da se nastavi sa merama u cilju normalizacije jugoslovensko-albanskih odnosa. Predloženo je da se određenim kosovskometohijskim preduzećima omogući malogranični promet sa Albanijom bez prethodnog sklapanja međudržavnog sporazuma Jugoslavije i Albanije. SIV je dao podršku širenju kulturne saradnje između Kosova i Metohije i Albanije. U vezi sa problemom drumskog saobraćaja i transportom jugoslovenske robe i putnika kroz Albaniju, SIV je predložio da se preduzeću „Kosmet-prevoz“ iz Prištine daju ovlašćenja da takva pitanja neposredno reguliše sa albanskom stranom. ${ }^{7}$ Spoljnopolitički odbor Savezne skupštine je u oktobru iste godine podržao pomenute predloge i zaključio da unapređenje odnosa sa Albanijom treba da bude ,dugoročan kurs jugoslovenske politike“ ${ }^{8}$ Nastojanje za poboljšanjem odnosa sa Albanijom istaknuto je u zaključcima Komisije za međunarodne odnose Saveza komunista Jugoslavije. ${ }^{9}$

Partija rada Albanije dosta kasno je uvidela značaj promena u Jugoslaviji i mogućnosti koje su joj one donosile po pitanju uticaja na Kosovu i Metohiji. Albanski listovi Zeri i populit i Baškimi objavljivali su do kraja šezdesetih godina članke o degeneraciji jugoslovenskog društva i propasti jugoslovenske ekonomije, dok su albanski funkcioneri iznosili najteže optužbe na račun jugoslovenskog rukovodstva. ${ }^{10}$ Enver Hodža je tvrdio da je ,politika Tita politika američkog imperijalizma, čiji je cilj uništenje socijalizma“". ${ }^{11}$

Agresivna retorika Envera Hodže prema Jugoslaviji bila je u raskoraku sa spoljnopolitičkim položajem, kao i sa ekonomskim i vojnim kapacitetima Albanije šezdesetih godina. Nakon razlaza sa Sovjetskim Savezom 1961. godine, čiji je jedan od razloga bilo upravo Hodžino protivljenje pomirenju sa Jugoslavijom na kojem je insistirao Hruščov, Albanija sa našla u istovremenom sukobu sa obe svetske supersile. ${ }^{12}$ Spoljnopolitički oslonac Enver Hodža je našao u Kini, dok stav prema susednoj Jugoslaviji nije promenio. ${ }^{13}$ Tokom

${ }^{7}$ DA MSP, PA, Albanija, 1969, f. 2, d. 15, Dopis Miše Pavićevića Komisiji za koordinaciju pregovora i susreta u SIV-u.

${ }^{8}$ DA MSP, PA, Albanija, 1968, f. 1, d. 2, Informacija Državnog sekretarijata za inostrane poslove o aktuelnom stanju jugoslovensko-albanskih odnosa, 23. 2. 1968.

${ }^{9}$ Arhiv Kosova (AK), Lidhja e Komunistëve të Kosovës, Pokrajinski komitet SKS za Kosovo i Metohiju. Neki problemi odnosa SFR Jugoslavije i NR Albanije. Priština, januar 1968; M. Gatalović, Burna vremena, 260.

${ }^{10}$ Elez Biberaj, Albania and China: A Study of an Unequal Alliance (Tirana: Albanian Institute for International Studies, 2014), 55.

${ }^{11}$ Arkivi Qendror Shtetëror (AQSH), fondi (f.) 10, Enver Hoxha, gruppi (g.) II, nëndarja (n.) III, viti (v.) 1966, dosja (d.) 183, Shënime dorëshkim të Shokut Enver Hoxha „Likuidimi i Rankoviçit", 13. 7. 1966.

12 Aleksandar Životić, Jugoslavija, Albanija i velike sile (1945-1961), (Beograd: Arhipelag Institut za noviju istoriju Srbije, 2011), 635-639; Aleksandar Životić, „Zaoštravanje jugoslovensko-sovjetskih odnosa u senci sovjetsko-albanskog sukoba (1959-1961)“, Vojnoistorijski glasnik, br. 1, (2010), 90-92; Miranda Vickers, The Albanians. A modern History (London: I.B: Taurus, 2011), 185-191.

${ }^{13}$ E. Biberaj, Albania and China; Ylber Marku, Sino-Albanian relations during the Cold War, 1949-1978: an Albanian perspective (doctoral dissertation, Lingang University, Department of History, 2017), 96-98. 
1967. i 1968. godine antijugoslovenska kampanja nije obustavljena, a albanski funkcioneri optuživali su jugoslovensku vlast za ugnjetavanje Albanaca, služenje američkim interesima, kapitalističku ekonomsku politiku i izdaju socijalističkih ideala. $^{14}$

Londonski Tajms je u novembru 1967. konstatovao neuspeh jugoslovenskog pokušaja normalizacije odnosa sa Albanijom. ${ }^{15}$ Neuspeh su indirektno priznali i jugoslovenski komunisti, pošto je na zajedničkoj sednici Predsedništva i Izvršnog komiteta CK SKJ u martu 1968. zaključeno da su napori jugoslovenskog rukovodstva u poboljšanju odnosa sa Albanijom ,dali vrlo skromne rezultate". ${ }^{6}$

\section{Prekretnica u odnosima: Zajedničke konferencije 1968. godine}

Dok je prema Jugoslaviji zadržala neprijateljski stav, Albanija je krajem 1967. godine počela da prihvata ponude Prištine za ostvarivanje kontakata sa Albancima u Jugoslaviji, kao i da upućuje svoje predloge za saradnju. Vlasti u Tirani su u komunikaciji sa kosovskometohijskim organima isticale albansko nacionalno zajedništvo. U albanskom odgovoru na poziv Pokrajinskog odbora Saveza boraca da Albanija pošalje delegaciju na otvaranje spomenika u Prištini, između ostalog je poručeno: „Ubeđeni smo da će se na dan proslave, u znak poštovanja prema sinovima i kćerima Albanije, na mestu gde su oni položili svoje živote za slobodu, podići crvena zastava sa dvoglavim orlom i zlatnom zvezdom - naša nacionalna zastava, simbol borbe i pobede čitavog albanskog stanovništva“". ${ }^{17}$

Osnivanje Filozofskog i Pravno-ekonomskog fakulteta u Prištini 1960. i 1961. godine ubrzalo je pretvaranje ovog grada u centar albanske inteligencije u Jugoslaviji. U Prištinu su tada prešli profesori albanskog jezika na Filozofskom fakultetu u Beogradu Anton Četa i Idriz Ajeti, kao i saradnik Etnografskog instituta SANU Mark Krasnići. ${ }^{18}$ U Prištini je 1967. godine obnovljen rad Albanološkog instituta, naučne ustanove usmerene na istraživanje albanskog jezika, književnosti, istorije i kulture. ${ }^{19}$ Do prvih neposrednih susreta albanske inteli-

\footnotetext{
${ }^{14}$ DA MSP, PA, Albanija, 1968, f. 1, d. 2, Informacija Državnog sekretarijata za inostrane poslove o aktuelnom stanju jugoslovensko-albanskih odnosa, 23. 2. 1968; AQSH, f. 10, g. III, n. IV, v. 1967, d. 300, Takim i shokut Enver Hoxha marrë me datën 2. 9.1967 me popullin e katundit rrapsh-stare të rrethit të Shkodrës dhe me përfaqessues të malësisë së kelmendit; Ethem Çeku, Kosovo and Diplomacy Since World War II: Yugoslavia, Albania and the Path to Kosovan Independence (London - New York: IB Taurus, 2016), 102-105.

${ }^{15}$ DA MSP, PA, Velika Britanija, 1967, f. 213, d. 3, Šifrovani telegram ambasade SFRJ u Londonu Državnom sekretarijatu za inostrane poslove, 1. 12. 1967.

16 AJ, 507, CK SKJ, III/130, Zajednička sednica Predsedništva i IK CK SKJ 11. marta 1968. godine, Prilog 1, str. 20.

${ }^{17}$ DA MSP, PA, Albanija, 1968, f. 1, 17. 11. 1967, d. 2, Informacija Državnog sekretarijata za inostrane poslove o aktuelnom stanju jugoslovensko-albanskih odnosa, 23. 2. 1968.

${ }^{18}$ Opširnije biografije albanskih naučnika u Jugoslaviji videti u: Vujadin Milanović, Univerzitet u Prištini u mreži velikoalbanske strategije (Beograd: Književne novine, 1990), 71-77.

${ }_{19}$ Albanološki institut u Prištini osnovan je 1953, a zbog promovisanja albanskog nacionalizma zatvoren je 1955. godine. Videti: Rexhep Qosja, Nezaštićena sudbina. O Albancima u Jugosla-
} 
gencije na Kosovu i Metohiji sa prosvetnim vlastima u Tirani došlo je u decembru 1967. godine, kada je delegacija profesora prištinskih fakulteta i naučnika Albanološkog instituta posetila Univerzitet u Tirani. Tada je postignut načelni dogovor o specijalizaciji kosovskometohijskih studenata na fakultetima u Tirani i uvozu albanskih udžbenika na Kosovo i Metohiju, ali do sklapanja zvaničnog ugovora ipak nije došlo. ${ }^{20}$

Obeležavanje 500-godišnjice smrti albanskog nacionalnog heroja Đurađa Kastriota Skenderbega 1968. godine iskorišćeno je da se odnosi Prištine i Tirane uzdignu na viši nivo. Albanija je organizovala niz manifestacija kulturnog i naučnog karaktera, a najveću je predstavljao svetski kongres albanologa od 12. do 18. januara 1968. godine. Tirana je Skupštini Autonomne pokrajine Kosova i Metohije uputila zvaničan poziv da na ovaj događaj uputi veliku delegaciju predstavnika albanskog naroda. ${ }^{21}$ Pokrajinsko rukovodstvo u Prištini odlučilo je da na kongres pošalje grupu profesora prištinskih fakulteta. Delegaciju su predvodili lingvisti Idriz Ajeti i Anton Četa, a u njoj su bili i ostali pripadnici albanske intelektualne elite u Jugoslaviji, poput sociologa i direktora Albanološkog instituta Fehmija Aganija, pravnika Surije Pupovcija i istoričara Zefa Mirdite. ${ }^{22}$

Jugoslovensko poslanstvo u Albaniji obavestilo je Sekretarijat inostranih poslova da je Tirana iskoristila kongres za velikoalbansku propagandu i iznošenje teritorijalnih pretenzija prema delu Jugoslavije. Istoričar i profesor Univerziteta u Tirani Aleks Buda je delegaciji mađarskih albanologa na skupu saopštio da Albanija radi na prikupljanju dokumentacije na osnovu koje će ,dokazati da su Kosovo i Metohija albanske teritorije“, nakon čega će ,zatražiti pripajanje ove teritorije Albaniji““. ${ }^{23}$ Mađarsko poslanstvo je obavestilo jugoslovensko poslanstvo o ovom razgovoru, uz zaključak da je albanska vlast htela da proveri da li slične teritorijalne pretenzije ima i Mađarska, s obzirom na prisustvo njene nacionalne manjine u Jugoslaviji. Mađarska je $\mathrm{u}$ to vreme bila nenaklonjena ideji približavanja Albaniji i suprotstavljanja Jugoslaviji, tako da je njena diplomatija Beogradu poslala prijateljsku poruku da se ,teritorijalna pitanja prema socijalističkim zemljama ne mogu postavljati“ “24

Delegacija iz Prištine je $\mathrm{u}$ jednom trenutku odvojena od ostatka skupa $\mathrm{i}$ odvedena u salon, kako bi se sastala sa Politbiroom Partije rada Albanije na čelu

viji danas (Zagreb: HSLS, 1990), 44-45; Kosovo i Metohija: Vek važnih događaja 1912-2012 (Beograd: Institut za savremenu istoriju, 2012), 97-100; Historical dictionary of Kosova, editor Robert Elsie (Lanham: Scarecrow Press, 2004), 147.

${ }^{20}$ DA MSP, PA, Albanija, 1969, f. 1, d. 11, Šifrovani telegram poslanstva SFRJ u Tirani DISP-u, 12. 6. 1969; DA MSP, PA, Albanija, 1968, f. 1, d. 2, Informacija Državnog sekretarijata za inostrane poslove o aktuelnom stanju jugoslovensko-albanskih odnosa, 23. 2. 1968.

${ }^{21}$ DA MSP, PA, Albanija, 1969, f. 1, d. 2, Informacija Državnog sekretarijata za inostrane poslove o aktuelnom stanju jugoslovensko-albanskih odnosa, 23. 2. 1968.

${ }^{22}$ Esat Myftari, Kosova dhe Enver Hoxha (Tiranë: Botimet Princi, 2016), 66-69; M. Gatalović, Burna vremena, $265,338$.

${ }^{23}$ DA MSP, PA, Albanija, 1968, f. 1, d. 2, Informacija Državnog sekretarijata za inostrane poslove o aktuelnom stanju jugoslovensko-albanskih odnosa, 23. 2. 1968.

${ }^{24}$ DA MSP, PA, Albanija, 1968, f. 1, d. 13, Telegram Poslanstva SFRJ u Tirani Državnom sekretarijatu za inostrane poslove, 14. 2. 1968. 
sa Enverom Hodžom. Predsednik Partije rada Albanije je najpre izrazio žaljenje što „drug Fadilj nije u Albaniju uputio širu delegaciju sa Kosova“. Hodža je poručio da treba nastaviti sa preštampavanjem knjiga iz Albanije na Kosovu i Metohiji i da za njega ne predstavlja problem da se prilikom preštampavanja izbaci njegova slika ukoliko se nalazila u originalu dela. On je izjavio i da je upoznat sa inicijativom da se određen broj Albanaca iz Jugoslavije školuje i usavršava na fakultetima u Albaniji, poručivši da je albanska strana spremna da obezbedi 200-300 stipendija za tu namenu. Albanski rukovodioci su naglašavali da se naučnicima iz Prištine ne obraćaju kao ,političari““ i „državnici“, već „kao Albanci“. Delegacija iz Prištine provela je narednih nekoliko dana u Albaniji, obilazeći veće gradove u zemlji. $^{25}$ Boravak albanskih intelektualaca sa Kosova i Metohije u Tirani u januaru 1968. rezultirao je sporazumom o prodaji knjiga iz Albanije Autonomnoj pokrajini Kosovo i Metohiji za potrebe pokrajinskog školskog sistema. Delegacija iz Prištine je pokrenula sa albanskom stranom razgovore o prijateljskim susretima fudbalskih ekipa i međusobnim posetama folklornih ansambala. ${ }^{26}$

Krupan korak na polju kulturnog povezivanja Albanaca iz Jugoslavije sa Albanijom učinjen je na naučnom savetovanju u Prištini 22. i 23. aprila 1968, na kojem je učestvovalo 150 albanskih intelektualaca iz Jugoslavije i Albanije. Pod uticajem političkih kretanja u Pokrajinskom komitetu Saveza komunista Srbije za Kosovo i Metohiju doneta je odluka da književni jezik Albanaca u Jugoslaviji više ne bude zasnovan na dijalektu Gega, korišćenom u Jugoslaviji, već na dijalektu Toska, kako bi se izjednačio sa književnim jezikom u Albaniji. ${ }^{27}$

U Prištini je 11. maja 1968. održan simpozijum posvećen Skenderbegu, na kojem je učestvovala delegacija Univerziteta u Tirani. Albansku delegaciju činili su univerzitetski profesori Aleks Buda, Ndreči Plasari, Bujar Hodža, Dorka Damo, Toma Murzaku i Mediha Šuterići. ${ }^{28}$ Delegacija je na Kosovu i Metohiji boravila jedanaest dana, od 8. do 18. maja, obilazeći značajnija mesta u pokrajini. Domaćini su gostima iz Albanije organizovali posete fabrikama tekstila i slatkiša, Albanološkom institutu, Pravno-ekonomskom i Filozofskom fakultetu u Prištini, Izdavačkoj kući ,Rilindja“ kao i nekoliko srednjih škola i gimnazija. ${ }^{29}$

${ }^{25}$ DA MSP, PA, Albanija, 1968, f. 1, d. 2, Telegram Poslanstva SFRJ u Tirani Državnom sekretarijatu za inostrane poslove, 25. 1. 1968; Sabyt Syla, „Qëndrimi i Shqipërisë ndaj demonstrative në Kosovë më 1968”, Studime Historike, nr. 3-4, (2012), 284.

${ }^{26}$ DA MSP, PA, Albanija, 1968, f. 1, d. 8, Šifrovani telegram Poslanstva Jugoslavije u Albaniji Državnom sekretarijatu inostranih poslova, 25. 1. 1968.

${ }^{27} \mathrm{Na}$ kongresu o albanskom pravopisu u Tirani 1972. godine lingvisti iz Albanije i Jugoslavije su zajedno doneli rezoluciju o pravopisu albanskog jezika, čime je potvrđeno jezičko jedinstvo Albanaca. Videti: Drejtshkrimi i Gjuhes Shqipe, redaktor Androkli Kostallari (Prishtinë: Instituti Albanologjik i Prishtinës, 1974), 10.

${ }^{28}$ Ana Lalaj, „1968-1969. Shkrirja e akujve në bashkëpunimin kulturor shiqipëri-kosove“, Studime Historike, nr. 3-4, (2015), 250; E. Myftari, Kosova dhe Enver Hoxha, 70; M. Gatalović, Burna vremena, 338.

${ }^{29}$ AQSH, f. 511, Ministria e Arsimit dhe e Kulturës, v. 1968, d. 30, Raport mbi vizitën e grupit të punonjësve shkencorë të universitetit shtetëror të Tiranës në Kosovë me rastin e simpoziumit kushtuar Skenderbeut, njësia arkivore (n.a.) 1. 
Prema izveštaju podnetom Ministarstvu prosvete Albanije, prilikom jedne zajedničke večere dekan Tehničkog fakulteta u Prištini počeo je da peva pesme o Titu, što su gosti iz Albanije doživeli kao provokaciju, pokazujući spremnost da demonstrativno napuste večeru. Veći incident su sprečili kosovski Albanci, koji su odmah zapevali drugu pesmu. ${ }^{30}$ Članovi albanske delegacije sa sobom su poneli 300 razglednica Albanije, 30 fotografija Envera Hodže i oko 3.000 bedževa sa Skenderbegom i albanskom zastavom. Fotografije i bedževi su podeljeni albanskoj omladini i u narednom periodu distribuirani su širom pokrajine. Služba državne bezbednosti je zbog toga nameravala da vozača autobusa albanske delegacije Tekija Malajnija protera iz zemlje. Albanski naučnici su poručili da će u tom slučaju oni demonstrativno napustiti konferenciju. Do proterivanja albanskog šofera ipak nije došlo, a profesori iz Tirane zamoljeni su da na skupu ne dele propagandni materijal. ${ }^{31}$

Albanski učesnici su zaključili da je skup o Skenderbegu u Prištini imao dvostruki karakter - „naučni“ i ,patriotski“, pošto je njegovo organizovanje obeleženo „snažnom patriotskom manifestacijom kosovskih Albanaca“. Albanski naučnici su naveli da su organizatori strahovali da se stvari ne otmu kontroli, tako da su vodili računa da patriotska manifestacija ne bude previše izražena i masovna. To je, po njima, bio razlog što je za simpozijum odabrana sala koja je imala „svega trista mesta“, pa su mnogi zainteresovani nastavnici i studenti iz Prištine ostali napolju. Nakon pritiska okupljenih, otvorena je i galerija, tako da je u sali bilo prisutno oko 500 učesnika. Predsednik organizacione komisije skupa Idriz Ajeti rekao je albanskoj delegaciji da se plašio da bi „neki provokator" mogao da podstakne studente da počnu sa neprikladnim skandiranjem ili pravljenjem incidenta, što bi, po njegovom mišljenju, onemogućilo kasnije organizovanje sličnih skupova posvećenih albanskoj istoriji i kulturi. Na skupu je učestvovao i srpski geograf $i$ etnolog Atanasije Urošević. ${ }^{32}$

Glavni referat podneo je istoričar iz Prištine Ali Hadri, čije izlaganje je po oceni albanske delegacije bilo na „niskom naučnom nivou“ i „svedeno na nabrajanje činjenica, bez pravog naučnog doprinosa“. Objašnjenje za ovakvu ocenu Hadrijevog izlaganja, pored toga što je Hadri profesionalno bio usmeren na izučavanje savremene a ne srednjovekovne istorije, može se pronaći i u tome što su albanski gosti Hadrija opisali kao naučnika „lojalnog titoističkom režimu“. Albanski učesnici skupa su kao najkvalitetniji referat ocenili izlaganje književnog kritičara Redžepa Ćosje na temu „Skenderbeg u poetskoj viziji Naima Frašerija“. 33

${ }^{30}$ AQSH, f. 511, v. 1968, d. 30, Raport mbi vizitën e grupit të punonjësve shkencorë të universitetit shtetëror të Tiranës në Kosovë me rastin e simpoziumit kushtuar Skenderbeut, n.a. 2.

${ }^{31}$ AQSH, f. 511, v. 1968, d. 30, Raport mbi vizitën e grupit të punonjësve shkencorë të universitetit shtetëror të Tiranës në Kosovë me rastin e simpoziumit kushtuar Skenderbeut, n.a. 2-3.

32 AQSH, f. 511, v. 1968, d. 30, Raport mbi vizitën e grupit të punonjësve shkencorë të universitetit shtetëror të Tiranës në Kosovë me rastin e simpoziumit kushtuar Skenderbeut, n.a. 4-5.

${ }^{33}$ AQSH, f. 511, v. 1968, d. 30, Raport mbi vizitën e grupit të punonjësve shkencorë të universitetit shtetëror të Tiranës në Kosovë me rastin e simpoziumit kushtuar Skenderbeut, n.a. 5. 
Pojedinim funkcionerima u Sekretarijatu za inostrane poslove zasmetalo je učešće istoričara Aleksa Bude na konferenciji, zbog njegove ranije najave da će Albanija zatražiti pripajanje Kosova. Sekretarijat za inostrane poslove izrazio je nezadovoljstvo što ga kosovskometohijske vlasti nisu obavestile o dolasku albanske delegacije u Prištinu, pa se o učešću Bude na konferenciji saznalo iz štampe. SSIP je uputio pismo Izvršnom veću Kosova i Metohije u kojem je zatražio da se ubuduće prilikom ovakvih poseta iz Albanije prethodno obaveste službe Sekretarijata inostranih poslova, kao i da im se nakon završetka posete dostavi referat o njenom sadržaju. ${ }^{34}$ Aleks Buda je izlaganje na konferenciji iskoristio da ospori naučno stanovište Halila Inaldžika o ,progresivnom karakteru osmanske vladavine u Albaniji“, kao i stanovište italijanskog albanologa Zefa Valentinija o Skenderbegovim ratovima kao „ratovima za odbranu hrišćanstva“, pošto se pomenuto stajalište nije uklapalo u romantičarsku viziju Skenderbega kao albanskog nacionalnog heroja. ${ }^{35}$

Jedan od organizatora novembarskih demonstracija u Prištini 1968. godine Adil Pireva je kao važan motiv za donošenje odluke o njihovom održavanju naveo zajedničke skupove naučnika iz Prištine i Tirane 1968. godine, što je, po njegovom mišljenju, dodatno podstaklo nacionalna osećanja kosovskometohijskih Albanaca. ${ }^{36}$ Istoričarka Ana Lalaj je konferencije o Skenderbegu i skup o jeziku Albanaca u Jugoslaviji 1968. godine označila kao „razbijanje leda u albansko-kosovskoj kulturnoj saradnji“، 37

U julu 1968. izdavačka preduzeća „Rilindja“ iz Prištine i „Arteks“ iz Tirane sklopila su ugovor o kupovini knjiga, gramofonskih ploča i učila iz Albanije za potrebe škola na Kosovu i Metohiji. Vrednost nabavke iznosila je 50.000 dolara i bila je uključena u trgovinski sporazum Jugoslavije i Albanije za 1968. godinu. Diplomatski krugovi u Tirani bili su začuđeni ovim gestom jugoslovenskih vlasti. Članovi rumunskog poslanstva u Albaniji poručili su jugoslovenskim diplomatama da ne mogu da razumeju zbog čega Jugoslavija u vreme izrazite antijugoslovenske kampanje u Albaniji nabavlja udžbenike iz te zemlje. ${ }^{38}$

Republički SUP Makedonije je 11. aprila 1969. obavestio Savezni sekretarijat za inostrane poslove da su u školskim knjigama i učilima koja se iz Albanije izvoze u Jugoslaviju proturani i materijali antijugoslovenske sadržine, poput izvoda iz članaka Zeri $i$ populit u kojima je napadana Jugoslavija i njeno rukovodstvo. Došlo je do zaplene određene količine materijala i blokade ulaska kamiona iz Albanije u Makedoniju. Vlasti u Prištini su saveznim jugosloven-

${ }^{34}$ DA MSP, PA, Albanija, 1968, f. 1, d. 8, Depeša Državnog sekretarijata za inostrane poslove Izvršnom veću AP Kosova i Metohije, 24. 5. 1968.

${ }^{35}$ AQSH, f. 511, v. 1968, d. 30, Raport mbi vizitën e grupit të punonjësve shkencorë të universitetit shtetëror të Tiranës në Kosovë me rastin e simpoziumit kushtuar Skenderbeut, n.a. 6.

${ }^{36}$ Adil Pireva, Demonstrat e para per Kosoven republike (1968). Kujtime (Prishtine: Faik Konica, 2016), 267-270, 278.

37 A. Lalaj, „1968-1969. Shkrirja e akujve në bashkëpunimin kulturor shiqipëri-kosove“, 249-274.

38 DA MSP, PA, Albanija, 1969, f. 1, d. 11, Šifrovani telegram Jugoslovenskog poslanstva u Tirani Državnom sekretarijatu za inostrane poslove, 4. 3. 1969. 
skim organima uputile žalbu zbog nepropuštanja kamiona sa ,školskim knjigama i učilima“" preko granice. ${ }^{39}$

Jugoslovensko poslanstvo u Tirani bilo je nezadovoljno ponašanjem organa Autonomne pokrajine Kosovo i Metohija u vezi sa kontaktima sa Albanijom. Poslanik Ljubomir Hrnjak je u telegramu od 11. juna 1969. zaključio da ustanove i organi sa Kosova i Metohije nisu u dovoljnoj meri obaveštavali SSIP i druge savezne i republičke institucije o dogovorima sa albanskom stranom. ${ }^{40}$ Hrnjakov telegram otkrivao je bojazan da je došlo do uspostavljanja paralelnih bilateralnih odnosa između Prištine i Tirane, nad kojim jugoslovenski Sekretarijat za inostrane poslove nije imao kontrolu. ${ }^{41}$

Vojin Lukić, nekadašnji savezni sekretar unutrašnjih poslova, koji je izbačen iz partije nakon Brionskog plenuma, u memoarima je naveo da su politički vrhovi Srbije i Jugoslavije bili informisani o ,direktnom i neuobičajenom povezivanju Kosova sa Albanijom“, kao i o sve većem mešanju i uticaju Tirane u naučnom, kulturnom i školskom životu Kosova i Metohije, ali su odlučili da tolerišu ovu pojavu. ${ }^{42}$ Pojedini srpski funkcioneri, poput Miloša Minića i Dobrivoja Radosavljevića Bobija, podrškom albanskim nacionalnim zahtevima na Kosovu nastojali su da steknu naklonost Josipa Broza i tako poboljšaju svoj položaj u partiji. ${ }^{43}$

Upečatljivo je da odluka jugoslovenskog partijskog vrha da omogući paralelne veze između Prištine i Tirane nije dovela do promene retorike albanskih rukovodilaca prema Jugoslaviji. Albanski vojni ataše u Pekingu je na prijemu 15. jula 1968. izjavio da na Albaniju ,spremaju napad američki imperijalizam, hruščovljevski revizionizam, grčki monarhofašizam i jugoslovenski revizionizam“. ${ }^{44} \mathrm{Ni}$ sovjetska invazija na Čehoslovačku, nakon koje je Albanija i formalno napustila Varšavski pakt, nije suštinski promenila odnose Albanije i Jugoslavije. Već sredinom oktobra 1968. partijski list Zeri i populit oštro je napao Jugoslaviju, a albanska obaveštajna služba učestvovala je u pripremanju nasilnih demonstracija u Prištini 27. novembra iste godine. ${ }^{45} \mathrm{U}$ decembru 1968.

${ }^{39}$ DA MSP, PA, Albanija, 1969, f. 2, d. 14, Dopis Državnog sekretarijata za inostrane poslove Saveznoj upravi carine, 8. 5. 1969.

${ }^{40}$ DA MSP, PA, Albanija, 1969, f. 1, d. 11, Šifrovani telegram poslanstva SFRJ u Tirani DSIP-u, 11. 6. 1969.

${ }^{41}$ Albanija je neprijateljstvo prema Jugoslaviji zadržala i tokom većeg dela 1968. godine, a do delimičnog poboljšanja odnosa došlo je na jesen 1968, usled zajedničkog straha od sovjetske invazije nakon Čehoslovačke krize. Videti: Aleksandar Životić, ,Jugoslavija, Albanija i Čehoslovačka kriza (1968-1971)“, Tokovi istorije, br. 3, (2012), 62-85.

${ }^{42}$ V. Lukić, $n$. d., 219.

${ }^{43}$ AS, Đ-2, f. 4 Centralni komitet Saveza komunista Srbije - materijali sa plenarnih sednica 1968, Četrnaesta plenarna sednica Centralnog komiteta SKS, održana 29. maja 1968. godine, str. 344; Venceslav Glišić, Susreti i razgovori. Prilozi za biografiju Petra Stambolića (Beograd: Službeni glasnik, 2010), 119-121; Veton Surroi, Fadil Hoxha në veten e pare (me shënime dhe parathënie të Veton Surroi) (Prishtinë: Koha, 2010), 367.

${ }^{44}$ DA MSP, PA, Albanija, 1968, f. 2, Šifrovani telegram DSIP-u iz Pekinga, 15. 7. 1968.

${ }^{45}$ DA MSP, PA, Albanija, 1969, f. 1, d. 8, Šifrovani telegram ambasade SFRJ iz Brisela, 26. 8. 1969; A. Životić, „Jugoslavija, Albanija i Čehoslovačka kriza (1968-1971)“, 73-75. 
u Tirani je objavljena knjiga Istorija Partije rada Albanije u kojoj je iznet niz optužbi na račun jugoslovenske partije. ${ }^{46}$

Normalizacija jugoslovensko-albanskih odnosa krajem šezdesetih godina zapravo nije interesovala ni jedno ni drugo rukovodstvo. Josip Broz i njegovo okruženje bili su zainteresovani za albanizaciju Kosova i Metohije i destabilizaciju Srbije kroz izdvajanje pokrajina iz opsega njene vlasti. Zbog toga su dozvolili Tirani da ostvaruje neposredan politički, kulturni i ekonomski uticaj na Kosovu, čak i bez prethodne normalizacije odnosa sa Beogradom. Edvard Kardelj i Vladimir Bakarić su na sednici Proširenog biroa Predsedništva SKJ 31. oktobra 1968. zatražili jačanje albanske autonomije i povezivanje Kosova sa Albanijom, zastupajući stav da dugoročan kurs politike SKJ treba da bude ujedinjenje Albanaca. Kardelj je poručio da se položaj kosovskih Albanaca ne može porediti sa položajem ostalih nacionalnih manjina u svetu, jer oni čine kompaktnu većinu na Kosovu, te da je opravdano postaviti problem da li Kosovo treba da pripadne Jugoslaviji ili Albaniji. Komunisti se moraju boriti za poboljšanje odnosa sa Albanijom i ukidanje postojeće granice između Kosova i Albanije kako ona ,više ne bi bila granica koja deli jedan narod“, istakao je Kardelj. ${ }^{47}$ Vladimir Bakarić je preporučio da se otklone smetnje za naseljavanje Kosova iz Albanije: „Smatram da bi trebalo razvijati autonomiju upravo tako da taj deo Albanaca koji ovde žive postanu jedan ne samostalni, nego jedan aktivni živi centar za razvijanje albanske nacije sa jednom perspektivom daljeg ujedinjavanja sa Albancima tamo. Zato je naravno potrebno razvijati bratstvo i jedinstvo i srediti režim odnosa naseljenja na Kosmetu“. 48 Članovi Proširenog biroa Predsedništva SKJ iz CK Srbije Petar Stambolić i Mijalko Todorović nisu se usudili da repliciraju Kardelju i Bakariću i ospore njihove stavove. Marko Nikezić, koji je kao sekretar inostranih poslova stvarao institucionalni okvir za povezivanje Tirane i Prištine, krajem 1968. nagrađen je postavljanjem na čelo Saveza komunista Srbije.

\section{Uspostavljanje ekonomske saradnje}

Važan korak ka uspostavljanju direktnih ekonomskih veza Kosova i Albanije bila je odluka SIV-a od 8. marta 1967. da se omogući malogranični promet robe između preduzeća sa Kosova i Metohije i Albanije bez prethodnog sklapanja međudržavnih sporazuma. ${ }^{49}$ Pokrajinski komitet Saveza komunista Srbije za Kosovo i Metohiju je početkom 1968. godine zaključio da je neophodno posvetiti veću pažnju malograničnom prometu između Kosova i Metohi-

\footnotetext{
${ }^{46}$ DA MSP, PA, Albanija, 1969, f. 1, d. 16, Beleška Državnog sekretarijata za inostrane poslove o Istoriji partije rada Albanije izdate decembra 1968. godine, 30. 1. 1969.

${ }^{47}$ AJ, 507, CK SKJ, Prošireni Biro Predsedništva CK SKJ, III-K. 2/2, Stenografske beleške sa Proširene sednice Biroa Predsedništva CK SKJ održane 31. 10. 1968, 24-26.

${ }^{48}$ AJ, 507, CK SKJ, Prošireni Biro Predsedništva CK SKJ, III-K. 2/2, Stenografske beleške sa Proširene sednice Biroa Predsedništva CK SKJ održane 31. 10. 1968, 38-39.

49 DA MSP, PA, Albanija, 1969, f. 2, d. 15, Izvod iz dopisa Saveznog izvršnog veća Državnom sekretarijatu za inostrane poslove, 17.3. 1967.
} 
je i Albanije, kao i da je potrebno ostvariti više neposrednih kontakata sa privrednicima iz Albanije. ${ }^{50} \mathrm{U}$ narednom periodu došlo je do niza međusobnih poseta delegacija vodećih albanskih i kosovskometohijskih preduzeća tokom kojih su postizani sporazumi o trgovini i saradnji.

Jugoslavija i Albanija su 1967. godine potpisale sporazum o turističkoj saradnji, prema kojem je Jugoslavija turistima sa crnogorskog i dubrovačkog primorja organizovala izlete u Albaniju. Sporazum je sklopljen uprkos tome što je Albanija odbila da ukine zabranu ulaska u zemlju jugoslovenskim državljanima nealbanske nacionalnosti. ${ }^{51}$ Dok je ostalim Jugoslovenima ulazak u Albaniju bio zabranjen, posete kosovskometohijskih Albanaca rođacima u Albaniji pretvorene su krajem šezdesetih godina u opširne turističke poduhvate, $u$ vidu grupnih poseta gradovima u Albaniji. Ove posete imale su i propagandni karakter, a Albanija je gostima iz Jugoslavije pokazivala svoja velika privredna preduzeća, koja su trebala da predstavljaju svedočanstvo o ekonomskom prosperitetu Enver Hodžine Albanije. ${ }^{52}$

Otpravnik poslova Poljske u Tirani Pjotr Glovacki je u oktobru 1969. sastavio izveštaj o jugoslovensko-albanskim odnosima, u kojem je zaključio da su ,nastojanja jugoslovenske strane da se poboljšaju odnosi sa Albanijom došla do izražaja u nizu inicijativa i predloga, ali su Albanci prihvatili samo one koji su odgovarali njihovim interesima“. On je naveo da su „Albanci u prvom redu išli za tim da pojačaju propagandu i uticaj na albansko stanovništvo u Makedoniji, Srbiji i Crnoj Gori“. Pjotr Glovacki je zaključio da se u tom cilju koriste posete Albanaca iz Albanije njihovoj rodbini u Jugoslaviji. ${ }^{53}$ Jugoslovensku politiku „pružene ruke“ Tirana je iskoristila da se poveže sa Kosovom, ne odustajući od agresivne retorike prema jugoslovenskom političkom vrhu. „Imamo i imaćemo trgovinske odnose sa Jugoslavijom, ali to neće dovesti do pojave našeg pozitivnog stava prema jugoslovenskoj politici prema Albancima“, poručio je Enver Hodža 1969. godine. ${ }^{54}$

Preduzeće „Prehrana“ iz Đakovice ostvarilo je 1968. godine sa Albanijom promet u iznosu od 200.000 dolara, a za 1969. godinu potpisalo je ugovore u vrednosti od 380.000 dolara. Prema izveštaju ambasade SFRJ u Tirani, predstavnici ovog preduzeća su razvili specijalne odnose sa albanskim vlastima, uvek nailazeći na pozitivan prijem u Tirani. „Prehrana“ je saradnju sa Albanijom proširila na potpuno različite grane od prehrambene industrije kao njene primarne delatnosti. Iz Albanije je na Kosovo uvozila kožu, cement, cigarete i

${ }^{50}$ AK, Lidhja e Komunistëve të Kosovës, 1968, Pokrajinski komitet SKS za Kosovo i Metohiju. Neki problemi odnosa SFR Jugoslavije i NR Albanije. Priština, januar 1968, str. 30.

${ }^{51}$ DA MSP, PA, Albanija, 1967, f. 2, d. 10, Ugovor sklopljen između preduzeća Albturist Tirana i preduzeća Putnik Beograd u vezi organizacije izleta tranzitnih turista, 1. 2. 1967.

52 DA MSP, PA, Albanija, 1969, f. 1, d. 12, Telegram Državnog sekretarijata inostranih poslova Poslanstvu SFRJ u Tirani, 28. 7. 1969.

${ }^{53}$ DA MSP, PA, Albanija, 1969, f. 1, d. 12, Telegram Jugoslovenskog poslanstva u Tirani Državnom sekretarijatu inostranih poslova, 9. 10. 1969.

${ }^{54}$ AQSH, f. 10, g. III, n. IV, v. 1969, d. 337/1. Bisedë e shokut Enver Hoxha, më datën 1.3.1969 me patriotin plak Kosovar Rexhep Duraku, babai i dëshmorit Emin Duraku, 1. 3. 1969, n.a. 14. 
konzerve, a u Albaniju izvozila gumene čizme, trikotažu i tekstil. Nakon novembarskih demonstracija na Kosovu 1968. godine i pojačane kontrole carine na granici sa Albanijom, otkriveno je da je „Prehrana“ iz Albanije uvozila i brojne predmete od drveta, među kojima su bili i albanski nacionalni simboli. ${ }^{55}$ Savezna uprava carina je 19. juna 1969. obavestila Državni sekretarijat za inostrane poslove da je u kamionima koji su zvanično prenosili prehrambene proizvode, „Prehrana“ iz Albanije na teritoriju Kosova prenosila albanske zastave i izrađevine u obliku dvoglavih orlova sa glavom Skenderbega. ${ }^{56}$

Vodeću ulogu u ekonomskom povezivanju Kosova i Albanije imalo je preduzeće „Kosmet-prevoz“ iz Prištine. Direktor ovog preduzeća Ali Jahja prilikom posete Tirani nastupao je „u ime cele privrede Kosova i Metohije“ i albanskim sagovornicima iznosio predloge koji se nisu ticali samo neposrednog poslovanja „Kosmet-prevoza“. Jahja je vodio pregovore o transportu uglja iz Poljske za Albaniju preko teritorije Jugoslavije, čiji ishod je bio sporazum prema kojem je „Kosmet-prevoz“ železnicom prevozio ugalj do Prizrena, a odatle kamionima do Kukesa. Jahja je Albancima nudio korišćenje kapaciteta fabrike rezervnih delova u Peći i fabrike akumulatora u Trepči, a dogovarao je i način transporta školskih knjiga iz Albanije za Kosovo. On je predložio da se deo školskih knjiga direktno prevozi kamionima iz Albanije do Prištine, a da ostatak bude prenet u kamionima koji prevoze hrom. ${ }^{57}$

Direktor „Kosmet-prevoza“ je predložio albanskoj strani organizovanje turističkih poseta između Albanije i Kosova, ali samo ljudi koji imaju porodice ili rođake sa druge strane granice, znajući da će Albanija tim ljudima obezbediti vize. Pomenuti predlozi Prištine za ekspanziju kosovsko-albanske ekonomske saradnje iznošeni su dva i po meseca nakon nasilnih demonstracija na Kosovu i Metohiji, za čije organizovanje je jugoslovenski vrh indirektno optužio i Albaniju. „Kosmet-prevoz“ je u 1969. godini ostvario trgovinsku saradnju sa Albanijom u vrednosti od 675.000 dolara. ${ }^{58}$

U Tirani su bili aktivni i predstavnici firme „Kožar“ iz Kosovske Mitrovice koji su albanskoj strani predložili poslove u vrednosti od milion dolara, kao i „Progresa“ iz Prizrena koji su zaključili ugovore o razmeni poljoprivrednih proizvoda. ${ }^{59} \mathrm{Za}$ razliku od intenzivne privredne saradnje nakon Drugog svetskog rata, koja je vodila ka postepenom uključivanju Albanije u jugoslovenski privredni prostor, ekonomski sporazumi od 1966. do 1969. godine delovali su u pravcu privrednog povezivanja Kosova i Metohije sa Albanijom.

${ }^{55}$ DA MSP, PA, Albanija, 1969, f. 2, d. 14, Dopis Savezne uprave carina Državnom sekretarijatu za inostrane poslove, 19. 6. 1969.

${ }^{56}$ Isto.

${ }^{57}$ DA MSP, PA, Albanija, 1969, f. 2, d. 14, Šifrovani telegram Ambasade u Tirani Državnom sekretarijatu za inostrane poslove, 7. 3. 1969.

58 DA MSP, PA, Albanija, 1969, f. 2, d. 14, Šifrovani telegram Ambasade SFRJ u Albaniji Državnom sekretarijatu za inostrane poslove, 1. 4. 1969.

59 DA MSP, PA, Albanija, 1969, f. 2, d. 14, Šifrovani telegram Ambasade SFRJ u Albaniji Državnom sekretarijatu za inostrane poslove, 24. 6. 1969. 
Veze sa Albanijom ostvarilo je i preduzeće rudnika hroma „Deva“ iz Đakovice. Grupa predstavnika rudnika „Deva“ je 17. januara 1968. posetila albanski grad Pogradec i zaključila sporazum sa preduzećem „Eksportal“ o izvozu celokupne količine hromne rude iz robnih lista za 1968. godinu. Predstavnici „Eksportala“ su posetili Đakovicu 8. februara 1968. i sa rudnikom „Deva" zaključili ugovor o izvozu 12.000 tona hromne rude preko robnih lista. Oni su razgovarali i sa predstavnicima „Kosmet-eksporta“ i „Progresa“. Kosovskometohijske i albanske vlasti su 1968. godine postigle sporazume o albanskim isporukama voća, povrća, svinjskog mesa i konzervi. ${ }^{60}$

Jugoslovenska ambasada u Tirani je 1969. godine zaključila da Albanija ekonomskoj saradnji sa Kosovom prilazi sa političkim kalkulacijama. U prilog tome, naveden je podatak da je Albanija u prethodnom periodu odbila ponude da učestvuje na Sajmu vina u Ljubljani i Poljoprivrednom sajmu u Novom Sa$\mathrm{du}$, ali je nakon toga predstavnicima preduzeća „Kosmet-eksport“ predložila da se u Prištini organizuje degustacija alkoholnih pića iz Albanije. ${ }^{61}$

Nakon donošenja amandmana na Ustav Srbije i usvajanja Ustavnog zakona Socijalističke autonomne pokrajine Kosovo početkom 1969. godine, pokrajina je stekla ovlašćenje da ,podstiče i pomaže razvoj međunarodnih veza na području privrede, obrazovanja, nauke, kulture, sredstava informacija i fizičke kulture“. ${ }^{62}$ To je dovelo do učvršćivanja postojećih i razvijanja novih odnosa Prištine i Tirane u sferi prosvete, turizma i privrede. Sekretar albanskog poslanstva u Jugoslaviji Hajrula Koburi je prilikom sastanka u Prištini sa rukovodiocem izdavačke kuće „Rilindja“ Idrizom Redžom u vezi sa distribucijom albanskih udžbenika u pokrajini, izrazio želju da se upozna sa tekstom Ustavnog zakona SAP Kosova. Redža mu je obećao da će „Rilindja“ dostaviti pet primeraka poslanstvu Albanije u Beogradu. Oni su pričali o produbljivanju kulturne i prosvetne saradnje, a rukovodilac „Rilindje“ je poručio da su „dobri odnosi u obostranom interesu Tirane i Prištine“. ${ }^{63}$

Još važniji ustupak od omogućavanja ekonomskog povezivanja sa Albanijom predstavljalo je obavezivanje jugoslovenskog državnog vrha na ekonomsku i finansijsku pomoć Kosovu. U Rezoluciji Devetog kongresa SKJ iz 1969. godine navedeno je da će Fond federacije za kreditiranje privredno nerazvijenih republika i pokrajina „kao vid kompenzacije i element solidarnosti u međunacionalnim odnosima dobiti trajne i stabilne izvore

${ }^{60}$ DA MSP, PA, Albanija, 1968, f. 1, d. 2, Informacija Državnog sekretarijata za inostrane poslove o aktuelnom stanju jugoslovensko-albanskih odnosa, 23. 2. 1968.

${ }^{61}$ DA MSP, PA, Albanija, 1969, f. 2, d. 14, Šifrovani telegram Ambasade SFRJ u Albaniji Državnom sekretarijatu za inostrane poslove, 24. 6. 1969.

${ }^{62}$ Dragoslav Marković, Život i politika 1967-1978, Knjiga prva (Beograd: Rad, 1987), 121; Ustavni amandmani sa ustavnim zakonom za sprovođenje ustavnih amandmana V $i$ VII (Beograd, 1969), 7-10; Službeni list Socijalističke autonomne pokrajine Kosova, 1969, 170; Ilija Vuković, Autonomaštvo i separatizam na Kosovu (Beograd: Nova knjiga, 1985), 90-91.

${ }^{63}$ DA MSP, PA, Albanija, 1969, f. 1, d. 4, Informacija sa sastanka održanog u odeljenju za izdavanje školskih udžbenika NIP-a Rilindja u Prištini 9. 5. 1969. godine sa sekretarom albanskog poslanstva H. Koburijem. 
sredstava“. ${ }^{64}$ U Rezoluciji je navedeno i da „posebnu pažnju treba posvetiti bržem razvoju SAP Kosova“, čime je dotiranje razvoja privrede Kosova predstavljeno kao svojevrsna obaveza jugoslovenske federacije. ${ }^{65}$

Direktor prištinskog preduzeća „Kosmet-prevoz“ predložio je početkom 1969. godine međusobne grupne ekskurzije omladine sa Kosova i Albanije za praznike poput 1. maja i 29. novembra. Predložio je i da "Kosmet-prevoz“ organizuje turističke izlete u Albaniju za Albance iz Turske koji tokom leta posećuju rodbinu na Kosovu i Metohiji. Dok su jugoslovenski diplomatski predstavnici pokušavali da se izbore za ukidanje zabrane ulaska nealbancima iz Jugoslavije u Albaniju, prištinski predstavnici u pregovorima sa albanskim vlastima ovo pitanje nisu pokretali. ${ }^{66}$

\section{Saradnja Univerziteta u Tirani i Univerziteta u Prištini}

Zbližavanje Prištine i Tirane intenzivirano je 1969. godine, a albanski lider Enver Hodža i neformalni vođa Albanaca u Jugoslaviji Fadilj Hodža komunicirali su preko posrednika, razmenjujući poruke lojalnosti i albanskog jedinstva. ${ }^{67}$ U maju 1969. Albaniju je posetila delegacija porodica albanskih narodnih heroja sa Kosova. Enver Hodža se tada susreo sa članom delegacije Redžepom Durakuom, koji je ujedno bio poznanik Fadilja Hodže. Predsednik Partije rada Albanije je tada poručio da je od svih albanskih funkcionera u Savezu komunista Jugoslavije oduvek „najviše poverenja imao u Fadilja Hodžu““ ${ }^{68} \mathrm{~S}$ druge strane, Fadilj Hodža, koji je na Devetom kongresu 1969. godine izabran za člana Izvršnog biroa Predsedništva SKJ, poručio je u septembru 1970. albanskom ambasadoru u Jugoslaviji Liku Seitiju da bi u slučaju napada bilo koje zemlje na Albaniju on lično bio „odani vojnik Envera Hodže“, kao i da se „nijedan Albanac iz Jugoslavije ne bi borio protiv Albanije“. Time je poslao poruku da bi se čak i u slučaju hipotetičkog sukoba između Jugoslavije i Albanije, on borio na strani Albanije. ${ }^{69}$

${ }^{64}$ Deveti kongres Saveza komunista Jugoslavije (Beograd: Komunist, 1969), 328-329.

${ }^{65}$ Isto.

${ }^{66} \mathrm{O}$ ekonomskom zatvaranju Kosova i Metohije prema Srbiji videti: DA MSP, PA, Albanija, 1969, f. 2, d. 14, Šifrovani telegram Ambasade SFRJ u Albaniji Državnom sekretarijatu za inostrane poslove, 1. 4. 1969; Žarko Papić, Vreme zastoja. Srbija 1968-1978 (Beograd: Ekonomika, 1990), 181-183; Momčilo Pavlović, „Kosovo under Autonomy 1974-1990“, Confronting The Yugoslav Controversies: A Scholars' Initiative, eds. Charles Ingrao and Thomas Emmert (West Lafayette, IN: Purdue University Press, 2009), 12.

${ }^{67}$ Prema mišljenju Ane Lalaj, komunikacija između Envera Hodže i Fadilja Hodže ostvarena je na jesen 1968. godine, kada je kosovskometohijsko rukovodstvo obavestilo Tiranu da su u pripremi ustavni amandmani koji će ojačati autonomiju Kosova i da bi zbog toga bilo korisno da Tirana privremeno obustavi antijugoslovensku kampanju. Videti: Ana Lalaj, „Ngjashmëri dhe pangjashmëri në lëvizjes e 1968-s (Një vështrim krahasues me demonstratat e shqiptarëve në Prishtinë, Tetovë dhe Shqipëri)", Studime Historike, nr. 3-4, (2018), 251-253.

${ }^{68}$ AQSH, f. 10, g. III, n. IV, v. 1969, d. 337/1. Bisedë e shokut Enver Hoxha, më datën 1.3.1969 me patriotin plak Kosovar Rexhep Duraku, babai i dëshmorit Emin Duraku, 1. 3. 1969, n.a. 13.

${ }^{69}$ AQSH, f. 10, g. III, n. IV, v. 1970, d. 387/1, Takimi i sekretarit të parë të KQ të PPSH, shokut Enver Hoxha me të ngarkuarin me punë të Republikës Popullore të Shqipërisë në Jugosllavi, Lik Seitin, në Tiranë, 19. 9. 1970, n.a. 2. 
Rektorat Univerziteta u Tirani uputio je 31. jula 1969. Ministarstvu prosvete Albanije „Memorandum o obnovi naučno-kulturne saradnje sa Kosovom“, u kojem je iznet pregled dotadašnje delatnosti kosovskih institucija na razvoju albanske kulture, kao i 16 predloženih mera za produbljivanje naučne i kulturne saradnje Tirane i Prištine. Predloženo je da albanske naučne institucije počnu direktno da šalju različite publikacije naučnim institucijama i fakultetima na Kosovu, kao i da se uspostavi neposredna saradnja naučnika i istraživača na što većem broju istraživačkih područja. Naučnicima iz Albanije je predloženo da se uključe u naučne rasprave koje su bile prisutne u pokrajini, poput rasprave o pravilima pravopisa, koju je pokrenuo Institut za albanski jezik i istoriju u Prištini. Predviđeno je zajedničko obeležavanje važnih godišnjica, organizovanje izložbi kao i predavanja albanskih profesora na Kosovu, odnosno kosovskih profesora u Albaniji. U daljoj budućnosti, planirana je i saradnja sa albanskim ustanovama u Skoplju. $^{70}$ Ministar prosvete Toma Deliana prosledio je memorandum zameniku premijera Albanije Haki Toski i ministru unutrašnjih poslova Ramizu Aliji. ${ }^{71}$

Ekspanzija kulturno-prosvetne saradnje sa Albanijom praćena je osamostaljivanjem pokrajinskih kulturnih i prosvetnih institucija u odnosu na republičke. Skupština Kosova je 1969. godine od postojeće mreže fakulteta i visokih škola u Prištini, Kosovskoj Mitrovici, Peći i Prizrenu formirala Univerzitet u Prištini. U januaru 1970. formiran je pokrajinski Zavod za udžbenike i nastavna sredstva, što je zvanično opravdano željom da se ,,rastereti republički Zavod za udžbenike“، 72

Univerzitet u Prištini i Državni univerzitet u Tirani sklopili su 1970. godine sporazum o nastavno-naučnoj saradnji. Sporazumom je predviđeno angažovanje profesora iz Tirane na prištinskim fakultetima, a obe strane su se saglasile da se sa upućivanjem profesora počne što ranije. U novembru 1970. na Univerzitet u Prištini su upućena prva četiri profesora iz Tirane. Šabanu Badžakuu dodeljen je predmet „Geometrijski elementi“، na Filozofskom fakultetu u Prištini. Tahir Hadžiimeri postavljen je za predavača na predmetu ,Mašinski materijal“" na Tehničkom fakultetu, Skender Čičo je zadužen za predmet „Histologija“ na Medicinskom fakultetu, a Androkli Kostalari za predmet „Istorija lingvističke teorije“" za studente albanskog jezika i književnosti. ${ }^{73}$

Ministarstvo prosvete Albanije uputilo je u decembru 1970. zahtev predsedniku Saveta ministara za upućivanje druge grupe profesora u Prištinu. Ovu grupu činilo je 27 profesora, angažovanih u različitim naučnim oblastima.

${ }^{70}$ AQSH, f. 511, v. 1969, d. 19, Përkujtesë në lidhje me gjallërimin e veprimtarisë shkencorekulturale në Kosovë dhe me qëndrimin tonë ndaj saj, n.a. 6-8.

${ }^{71}$ AQSH, f. 511, v. 1969, d. 19, Përkujtesë në lidhje me gjallërimin e veprimtarisë shkencorekulturale në Kosovë dhe me qëndrimin tonë ndaj saj, n.a. 25-26.

${ }^{72}$ Miomir Gatalović, ,Jugoslovenska državna politika na Kosovu i Metohiji 1958-1974“ (doktorska disertacija, Univerzitet u Beogradu, Filozofski fakultet, Odeljenje za istoriju, 2014), 809; Zoran Vukadinović, „Prištinski univerzitet i njegove biblioteke“, Savremena biblioteka, br. 25, (2008), 52-55.

${ }^{73}$ AQSH, f. 490, Kèshilli i Ministrave, v. 1970, d. 456, Letër e Ministrisë së Arsimit dhe Kulturës drejtuar Kryeministrit të Shqipërisë lidhur me dërgimin e një profesori në Universitetin e Prishtinës, n.a. $1-2$. 
Devet profesora predavalo je na inženjerskim i tehničkim smerovima, sedam na prirodno-matematičkim i medicinskim smerovima, a po jedan na ekonomiji i na pravu. Pored toga, devet profesora iz Albanije su organizovali ciklična predavanja na Univerzitetu u Prištini, uglavnom iz domena društvenih i lingvističkih nauka. Ekrem Čabej je predavao „Probleme istorije albanskog jezika“, Jorđi Đinari „Probleme dijalektologije albanskog jezika“, Mahir Domi „Sintaksičke probleme današnjeg albanskog jezika“, Stefanać Polo „Probleme jedinstva albanskog naroda“, a Aleks Buda „Epohu Skenderbega“ ${ }^{74} \mathrm{Uz}$ obaveštenje o prijavljenim profesorima, Ministarstvo prosvete Albanije uputilo je predsedniku Vlade i biografije svih kandidata za odlazak u Prištinu. ${ }^{75}$

Početkom januara 1971. u Prištinu je upućena treća grupa albanskih profesora, koju su činili Kolj Popa, Bardilj Goljemi, Munir Karađozi, Luan Voština, Pulumb Karauli, Koste Koci i Nadide Dinasi. Oni su održali predavanja na Medicinskom, Filozofskom i Tehničkom fakultetu Univerziteta u Prištini. ${ }^{76}$ Sedmočlanu delegaciju iz Tirane u Prištini je dočekao rektor Univerziteta u Prištini Derviš Rožaja, koji je u čast gostiju priredio posebnu ceremoniju. Na sastanku dve strane pokazalo se da je pokretanje širokog spektra kulturne saradnje Tirane i Prištine dovelo do novih otvorenih pitanja. Albanska delegacija je od Rožaje zatražila da reši pitanje distribucije albanskih tekstova, da se utvrdi tačan raspored dolaska albanskih predavača na Kosovo i da Univerzitet u Prištini, u skladu sa konvencijom iz 1970. godine, uputi svoje istraživače na specijalizaciju u Tiranu. Rožaja je poručio da je kosovska strana spremna da sve pomenute probleme „otkloni u što kraćem roku“. ${ }^{77}$

Na narednom sastanku Rožaje i Pope 6. aprila 1971. godine, rektor Univerziteta u Prištini poručio je da je rad predavača iz Tirane na Kosovu ,veoma pozitivno ocenjen čak i u visokim krugovima u Beogradu“. Rožaja je objasnio da su na taj način otklonjeni skepticizam i nepoverenje onih ljudi koji su tvrdili da „albanski predavači ne dolaze na Kosovo zbog nauke, nego zbog drugih stvari i propagande“ ${ }^{78}$ Popa se 9. aprila u hotelu „Božur“ u Prištini sastao sa svojim bivšim učenikom na Pedagoškoj školi u Elbasanu Elhamijem Nimanijem, koji je obavljao visoke dužnosti u jugoslovenskom partijskom rukovodstvu i Državnom sekretarijatu inostranih poslova. U trenutku sastanka sa Popom, Nimani je bio jugoslovenski ambasador u Libiji. Albanski profesor Popa je bio nezadovoljan razgovorom sa Nimanijem, kojem su prisustvovali i Fehmi Agani,

${ }^{74}$ AQSH, f. 490, v. 1970, d. 456, Letër e Ministrisë së Arsimit dhe Kulturës drejtuar Kryeministrit të Shqipërisë mbi grupin e dytë që do të shkojnë në Prishtinë për kurse ligjeratash, n.a. 4-5.

${ }^{75}$ AQSH, f. 490, v. 1970, d. 456, n.a. 6-36.

${ }^{76}$ AQSH, f. 511, v. 1971, d. 180, Relacione dhe informacione, mbi grupet e pedagogëve tanë të dërguar në Kosovë dhe të atyre të Kosovës në vendin tonë për Universitetin Shtetëror të Tiranës dhe Universitetin e Prishtinës, n.a. 7.

${ }^{77}$ AQSH, f. 511, v. 1971, d. 180, Relacione dhe informacione, mbi grupet e pedagogëve tanë të dërguar në Kosovë dhe të atyre të Kosovës në vendin tonë për Universitetin Shtetëror të Tiranës dhe Universitetin e Prishtinës, n.a. 8.

78 AQSH, f. 511, v. 1971, d. 180, Informacion paraprak mbi disa aspekte të punës së grupit te pestë në Pristinë, 12. 4. 1971, n.a. 32. 
Mahir Domin i Islam Zekon. Popi je zasmetalo što je Nimani izjavio da predavači iz Albanije na Prištinskom univerzitetu mogu da doprinesu razvoju jezičke nauke, ali da je za usavršavanje u tehničkim naukama neophodno školovanje na srpskim fakultetima sa dugom tradicijom. Albanskoj delegaciji se nije dopao ni zaključak Nimanija da je uvođenje standardnog književnog jezika Albanije u kosovski prosvetni sistem ,,samo unelo zbrku“ i pogoršalo stanje na tom polju. ${ }^{79}$

Tokom 1971. godine, 41 profesor sa Univerziteta u Tirani angažovan je kao predavač na nekom od fakulteta u Prištini. Pored toga, profesori književnosti Spiro Floći i Dalan Špalo su stručno angažovani u pokrajinskoj biblioteci, istoričar Toma Murzaku u Arhivu Kosova, dok je arheolog Damjan Kamata pomagao muzeju u Prištini, istražujući ilirske tragove u Jugoslaviji. ${ }^{80}$

U aprilu 1971. organizovana su prva predavanja prištinskih profesora na Univerzitetu u Tirani. Pravnik Surija Pupovci održao je predavanje na temu građansko-pravnih odnosa u Kanonu Leke Dukađinija, lingvista Idriz Ajeti obradio je temu dijalekta Albanaca u okolini Zadra, a etnograf Mark Krasnići je studentima u Tirani govorio o fenomenu velikih patrijarhalnih porodica na Kosovu. ${ }^{81}$ Četvrti predavač, sociolog Muhamet Pačuku, održao je predavanje o položaju albanskih žena na Kosovu. Nakon predavanja, prištinski profesori su Jorđiju Đinariju pričali o međunacionalnim sukobima na Kosovu i Jugoslaviji. ${ }^{82}$ Na sopstveni zahtev i uz odobrenje Univerziteta u Tirani, u Albaniji su od 24. maja do 4. juna 1971. boravili studenti albanske književnosti iz Prištine Ibrahim Rugova i Redžep Ismaili. Rugova je tada bio glavni urednik časopisa Novi svet, a Ismaili glavni urednik novoformiranog naučnog časopisa Znanje. ${ }^{83}$

Albanski profesori su po povratku iz Prištine Ministarstvu prosvete Albanije podnosili izveštaj o svom radu, kao i izveštaj o političkoj situaciji u Jugoslaviji, koji je prosleđivan Centralnom komitetu Partije rada Albanije. Nakon povratka iz Jugoslavije u aprilu 1971. godine, albanski predavači su podneli izveštaj o svim političkim aspektima posete Josipa Broza Kosovu, izgledu i sadržaju priređenih ceremonija i načinu dekoracije kosovskih gradova povodom ove svečanosti. ${ }^{84}$ Pro-

${ }^{79}$ AQSH, f. 511, v. 1971, d. 180, Mbi punën e grupit të pedagogëve të U.SH.T pranë Universitetit të Prishtinës gjatë periodës 28. III - 17. IV 1971, n.a. 44.

${ }^{80}$ AQSH, f. 511, v. 1971, d. 180, Relacion, 20. 7. 1971, n.a. 184-198.

${ }^{81} \mathrm{O}$ političkim pogledima Pupovcija, Ajetija i Krasnićija videti: AS, BIA, III-136, Izveštaj o neprijateljskoj delatnosti i antisocijalističkim pojavama u sredinama prosvetnih radnika, srednjoškolske i studentske omladine na Kosmetu, a.j. 17; Mark Krasnići, Savremene društvenogeografske promene na Kosovu i Metohiji (Priština: Muzej Kosova i Metohije, 1963), 34; Miloš Mišović, Ko je tražio republiku (Beograd: Narodna knjiga, 1985), 153-154.

${ }^{82}$ AQSH, f. 511, v. 1971, d. 180, Relacion mbi Qendrimin ne Shqiperi te profesoreve te UP Idriz Ajeti, Mark Krasniqi, Syrja Pupovci dhe ligjeruesit Muhamet Paçuku, n.a. 140-145.

${ }^{83}$ Prema izveštaju Mehmeta Elezija, Rugova je albanskim domaćinima pričao podrugljive šale na račun Josipa Broza, Aleksandra Rankovića i Fadilja Hodže, kao i viceve o „četnicima“ u Komunističkoj partiji Jugoslavije. Naglasio je da su mu Srbi ubili oca i dedu, a da su njega u nekoliko navrata pokušali da potkupe. Videti: AQSH, f. 511, v. 1971, d. 180, Relacion i shkurter mbi aktivitet me studentet kosovare Ibrahim Rugova dhe Rexhep Ismaili, n.a. 137-139.

${ }^{84}$ AQSH, f. 511, v. 1971, d. 180, Mbi punën e grupit të pedagogëve të U.SH.T pranë Universitetit të Prishtinës gjatë periodës 28. III - 17. IV 1971, Mbi disa aspekte të vizitës së Titos në krahinën e Kosovës, n.a. 45. 
fesor na Medicinskom fakultetu Skender Čičo je po dolasku iz Prištine u decembru 1971. obavestio albanske vlasti da je politička situacija u Jugoslaviji ,haotična“, da Hrvati zahtevaju otcepljenje od Jugoslavije, ulazak u Ujedinjene nacije, kao i to da Hrvatska banka uspostavi direktne kontakte sa međunarodnim finansijskim institucijama. Čičo je naveo i da je 70 studenata u Zagrebu uhapšeno pošto je prilikom pretresa studentskog doma u njihovim sobama pronađeno oružje. Izvestio je i o protestu srpskih studenata u Prištini, koji su se žalili na nacionalnu diskriminaciju od strane univerzitetskih i pokrajinskih vlasti. ${ }^{85}$

Albanske vlasti su ostvarile posebno blisku saradnju sa pojedinim kosovskim intelektualcima. Ministarstvo unutrašnjih poslova Albanije je informacije o stanju u Jugoslaviji dobijalo od književnika iz Prištine Hasana Mekulija. On je 1972. godine obavestio albanske vlasti da ,gotovo svi Kosovari koji se vrate iz Albanije pričaju pozitivno o toj zemlji“, a da onim malobrojnima koji govore negativno ,niko ne veruje“. Napomenuvši da pozitivne utiske iz Albanije imaju i srpski književnici koji su je posetili, Mekuli ističe da je lično pokrenuo ,veliku propagandnu kampanju u književnim krugovima na Kosovu i u Beogradu sa ciljem povećanja ugleda albanske države“ .86

Odbrana doktorske disertacije Redžepa Ćosje „Asdreni, život i delo“ u Beogradu 20. marta 1971. imala je vanredan značaj pošto su među članovima komisije za odbranu doktorske disertacije u Jugoslaviji prvi put bili i profesori Univerziteta u Tirani, Androkli Kostalari i Aleks Buda. ${ }^{87}$ Oni su u zajedničkom izveštaju obavestili Ministarstvo prosvete Albanije da je odbrana bila ,dostojanstvena“ i na „visokom naučnom nivou“. Buda i Kostalari su se u Prištini sastali sa direktorom Arhiva Kosova Ismetom Dermakuom, koji je poručio da je spreman da im ustupi arhivsku građu za koju procene da bi koristila njihovim istraživanjima. Dermaku je izrazio žaljenje što saradnja Arhiva Kosova i albanskih arhiva nije uspostavljena ranije, pokazujući spremnost da svu građu Arhiva Kosova stavi na raspolaganje Centralnom državnom arhivu Albanije i istorijskim i lingvističkim institutima u ovoj zemlji. ${ }^{88}$

\section{Zaključak}

Zahtev albanskih komunističkih rukovodilaca nakon Brionskog plenuma da se Kosovu i Metohiji omoguće specijalne veze sa Albanijom jugoslovensko rukovodstvo je ugradilo u spoljnopolitički program Državnog sekretarijata za inostrane poslove. Normalizacija odnosa sa Albanijom označena je kao cilj jugoslovenske spoljne politike, a kulturno i ekonomsko povezivanje Autonomne

${ }^{85}$ AQSH, f. 511, v. 1971, d. 180, Relacionin për punën e kryer nga shokët Skender Çiço dhe Ali Dedei gjate qendrimit ne Kosove ne muajin dhjetor 1971, n.a. 2-4.

${ }^{86}$ Podaci su prosleđeni sekretaru CK Partije rada Albanije Ramizu Aliji. Videti: AQSH, f. 14, Komiteti Qëndror, Arkivi i Partisë - Struktura, v. 1972, d. 428, Raporti nga Hasan Mekuli për situatën në Kosovë, 6. 6. 1972, 1.

${ }^{87}$ AQSH, f. 511, v. 1971, d. 180, Mbi mbrojtjen e disertacionit te doktorates te Rexhep Qoses ne Prishtine, n.a. 26-27.

${ }^{88} \mathrm{AQSH}$, f. 511, v. 1971, d. 180, Mbi Arkivin krahinor historic te Kosoves, n.a. 27-29. 
pokrajine Kosova i Metohije sa Albanijom DSIP je predstavio kao način za približavanje Jugoslavije i Albanije. Do kraja šezdesetih godina Priština i Tirana su uspostavile specijalne ekonomske, političke i prosvetne kontakte u koje jugoslovenske i srpske vlasti nisu imale neposredan uvid. Međutim, jugoslovenski partijski vrh je svesno omogućavao ove kontakte, pošto je u njima video važno sredstvo za slabljenje Srbije i jačanje dezintegrativnih procesa u zemlji. Naučne konferencije o Skenderbegu u Prištini i Tirani obeležene su snažnim nacionalnim nabojem, a sporazumi o uvozu albanskih knjiga na Kosovo i Metohiju omogućili su masovno širenje albanske literature i publicistike u Jugoslaviji.

Nakon uvođenja malograničnog prometa između Kosova i Metohije i Albanije, kosovskometohijska preduzeća su svoju proizvodnju preusmerila na albansko tržište. Dok je za ostale jugoslovenske državljane ulazak u Albaniju bio zabranjen, pokrajinska preduzeća su za Albance iz Jugoslavije organizovala višednevne turističke izlete u Albaniju. Korišćenjem školskih udžbenika iz Albanije na Kosovu i Metohiji i angažovanjem 41 profesora sa Univerziteta u Tirani kao predavača na prištinskim fakultetima izvršeno je delimično ujednačavanje obrazovnih sistema i integracija naučno-istraživačke delatnosti na albanskom jeziku. Prosvetna saradnja otvorila je prostor za snažan uticaj Albanije na Kosovu i Metohiji, a Tirana je u pokrajini razvila široku mrežu doušnika, koji su Partiju rada Albanije redovno izveštavali o situaciji na Kosovu i Metohiji, kao i o relevantnim političkim, ekonomskim i kulturnim problemima u jugoslovenskoj federaciji. Učešće jugoslovenskog sekretarijata inostranih poslova i spoljnopolitičke komisije Saveza komunista Jugoslavije u uspostavljanju ovakvih odnosa na Kosovu ukazuje na to da je krajem šezdesetih godina partijski vrh počeo da koristi državnu spoljnu politiku za unutrašnje slabljenje i postepenu dezintegraciju jugoslovenske države. 


\section{REFERENCE}

- Biberaj, Elez. Albania and China: A Study Of An Unequal Alliance. Tirana: Albanian Institute for International Studies, 2014.

- Çeku, Ethem. Kosovo and Diplomacy Since World War II: Yugoslavia, Albania and the Path to Kosovan Independence. London - New York: IB Taurus, 2016. https://doi.org/10.5040/9780755621750

- Ćosić, Dobrica. Lična istorija jednog doba. Vreme iskušenja 1951-1968. Beograd: Službeni glasnik, 2009.

- Qosja, Rexhep. Nezaštićena sudbina. O Albancima u Jugoslaviji danas. Zagreb: HSLS, 1990.

- Deveti kongres Saveza komunista Jugoslavije. Beograd: Komunist, 1969.

- Drejtshkrimi i Gjuhes Shqipe. Redaktor Androkli Kostallari. Prishtinë: Instituti Albanologjik i Prishtinës, 1974.

- Gatalović, Miomir. Burna vremena: Kosovo i Metohija u državnoj politici Jugoslavije 1966-1969. godine. Beograd: Institut za savremenu istoriju, 2018.

- Gatalović, Miomir. „Jugoslovenska državna politika na Kosovu i Metohiji 1958-1974“. Doktorska disertacija, Univerzitet u Beogradu, Filozofski fakultet, Odeljenje za istoriju, 2014.

- Glišić, Venceslav. Susreti i razgovori. Prilozi za biografiju Petra Stambolića. Beograd: Službeni glasnik, 2010.

- Historical dictionary of Kosova. Editor Robert Elsie. Lanham: Scarecrow Press, 2004.

- Kosovo i Metohija: Vek važnih događaja 1912-2012. Priredili Momčilo Pavlović, Dragomir Bondžić, Miomir Gatalović, Ivana Pantelić, Goran Antonić, Ratomir Milikić. Beograd: Institut za savremenu istoriju, 2012.

- Krasnići, Mark. Savremene društveno-geografske promene na Kosovu i Metohiji. Priština: Muzej Kosova i Metohije, 1963.

- Lalaj, Ana. „1968-1969. Shkrirja e akujve në bashkëpunimin kulturor shiqipëri-kosove“. Studime Historike, nr. 3-4, (2015), 249-274.

- Lalaj, Ana. „Ngjashmëri dhe pangjashmëri në lëvizjes e 1968-s (Një vështrim krahasues me demonstratat e shqiptarëve në Prishtinë, Tetovë dhe Shqipëri)“. Studime Historike, nr. 3-4, (2018), 237-259.

- Lukić, Vojin. Sećanja i saznanja. Aleksandar Ranković i Brionski plenum. Titograd: N. Jovović, 1989.

- Marković, Dragoslav. Život i politika 1967-1978, Knjiga prva. Beograd: Rad, 1987.

- Marku, Ylber. Sino-Albanian relations during the Cold War, 1949-1978: an Albanian perspective. Doctoral dissertation, Lingang University, Department of History, 2017.

- Milanović, Vujadin. Univerzitet u Prištini u mreži velikoalbanske strategije. Beograd: Književne novine, 1990.

- Mišović, Miloš. Ko je tražio republiku. Beograd: Narodna knjiga, 1985. 
- Myftari, Esat. Kosova dhe Enver Hoxha. Tiranë: Botimet Princi, 2016.

- Nikolić Kosta, i Srđan Cvetković. Srbi i Albanci na Kosovu i Metohiji u 20. veku (1912-1990). Beograd: Institut za savremenu istoriju, 2014.

- Papić, Žarko. Vreme zastoja. Srbija 1968-1978. Beograd: Ekonomika, 1990.

- Pavlović, Momčilo. „Kosovo under Autonomy 1974-1990“. Confronting The Yugoslav Controversies: A Scholars' Initiative. Eds Charles Ingrao and Thomas Emmert, 48-81. West Lafayette, IN: Purdue University Press, 2009. https://doi.org/10.2307/j.ctt6wq2r2.5

- Pireva, Adil. Demonstrat e para per Kosoven republike (1968). Kujtime. Prishtinë: Faik Konica, 2016.

- Surroi, Veton. Fadil Hoxha në veten e pare (me shënime dhe parathënie të Veton Surroi). Prishtinë: Koha, 2010.

- Syla, Sabit. „Qëndrimi i Shqipërisë ndaj demonstrative në Kosovë më 1968”. Studime Historike, nr. 3-4, (2012), 283-293.

- Šesta sednica CK Srbije. Aktivnosti Saveza komunista Srbije posle Četvrte sednice SK Jugoslavije. Beograd: Sedma sila, 1966.

- Ustavni amandmani sa ustavnim zakonom za sprovođenje ustavnih amandmana Vi VII. Beograd, 1969.

- Vidačić, Rajko. O korenima separatizma i terorizma na Kosovu. Beograd: Službeni glasnik, 2000.

- Vukadinović, Zoran. „Prištinski univerzitet i njegove biblioteke“. Savremena biblioteka, br. 25, (2008), 52-55.

- Vuković, Ilija. Autonomaštvo i separatizam na Kosovu. Beograd: Nova knjiga, 1985.

- Životić, Aleksandar. „Jugoslavija, Albanija i Čehoslovačka kriza (19681971)“. Tokovi istorije, br. 3, (2012), 62-85.

https://doi.org/10.31212/tokovi.2012.3.ziv.62-85 
IGOR VUKADINOVIĆ, PhD, Research Assistant

Institute for Balkan Studies SASA

Belgrade, Republic of Serbia

vukadinovicigor3@gmail.com

\section{CULTURAL AND ECONOMIC CONNECTION OF ALBANIA AND KOSOVO AND METOHIJA 1967-1971}

\section{Summary}

Major changes in the position of Kosovo and Metohija's autonomy in the late 1960s affected the province's relations with Albania. In 1967, the Yugoslav State Secretariat of Foreign Affairs and the Yugoslav Federal Executive Council began to encourage cultural and economic ties between Kosovo and Metohija and Albania, justifying this as a strategy for the normalization of relations between Yugoslavia and Albania. Following the joint commemorations of the anniversary of Skanderbeg's death in Priština and Tirana, an agreement was reached on the use of textbooks from Albania in the Kosovo and Metohija school system. The two sides organized mutual visits of folklore and art groups, as well as friendly matches of soccer teams. Kosovo companies were allowed small border traffic with Albania without any prior interstate agreements between Belgrade and Tirana. Constitutional changes in Serbia in 1969 enabled the expansion of economic and cultural cooperation between Kosovo and Albania. The University of Priština and the University of Tirana signed an agreement to hire professors from Tirana as lecturers at Priština faculties. In 1971, scientists from Tirana participated in the work of the Kosovo Archives, the Provincial Library, and the Priština Museum, while 41 Albanian professors gave lectures at the University of Priština. Reports by Albanian lecturers from Kosovo enabled the Albanian state leadership to be acquainted in detail with the political situation in Yugoslavia.

KEYWORDS: Albania, Kosovo and Metohija, Yugoslavia, Culture, Economy, University of Priština, University of Tirana 